\title{
Influence of vegetation cover on the biological traits of pond invertebrate communities
}

\author{
R. Céréghino ${ }^{1}$, A. Ruggiero ${ }^{2}$, P. Marty ${ }^{1}$, S. Angélibert ${ }^{3}$
}

${ }^{1}$ Ecolab, Laboratoire d'Ecologie Fonctionnelle, UMR 5245, Université de Toulouse, 118 route de Narbonne, 31062 Toulouse cedex 9, France.

${ }^{2}$ Dipartimento di Biologia, Università degli Studi di Roma Tor Vergata, Via della Ricerca Scientifica - 00133 Roma, Italy. ${ }^{3}$ University of Applied Sciences of Western Switzerland - EIL, Department of Nature Management, 150 route de Presinge, CH -1254 Jussy-Geneva, Switzerland

\begin{abstract}
Without human intervention, ponds progressively fill up with aquatic vegetation, so that the structure and age of the vegetal formations show great contrasts within a given set of water bodies. We hypothesized that the biological traits of pond invertebrate communities differed significantly among ponds having different vegetal formations. To test this hypothesis, we selected three neighbouring ponds showing a gradient of vegetation cover and type (sparse bryophytes on rocky substrata (pond 1), extensive submerged Chara beds (pond 2), aerial Typha stands (pond 3)), and we studied between-ponds variations in the combinations of species traits. Taxa biomass was monthly recorded in each pond over one year, to take into account species' seasonality. Species traits were described using a fuzzy-coding method and a simultaneous analysis of the two matrices (co-inertia analysis) was used to investigate changes in biological trait composition. Biomass increased from pond 1 to pond 3 , and was higher in vegetal than in muddy mesohabitats. Among 25 biological traits, 10 were significantly correlated to the distribution of samples: number of generations per year, cohort production interval, adult longevity, adult size, number of eggs per female, dispersal ability, dispersal mode, consumer level, ingested food type, and feeding group. Invertebrates in pond 1 species allocated much energy to reproduction, while in pond 3 resource use was favoured by larger body size, long-lived organisms, and a higher diversity of feeding groups. Our results suggest that the structure and age of the vegetal formation play role in selecting species traits related to population dynamics and feeding habits.
\end{abstract}

Keywords: species traits, life history, macroinvertebrates, co-inertia analysis, wetlands

\section{Introduction}

Ponds are small and shallow, natural or man-made water bodies, which typically outnumber larger lakes by a ratio of about 100 to 1 (Oertli et al. 2005, Nicolet et al. 2007). Recent studies have revealed their importance for aquatic biodiversity (Pyke 2005, Dimitriou et al. 2006, Scheffer et al. 2006, EPCN 2007) because, despite their small size, they disproportionately contribute to regional diversity, e.g., when compared to streams, large rivers, or lakes (Oertli et al. 2002, Williams et al. 2004, Karaus et al. 2005). To date, the structure of biological communities in ponds was mostly studied on the

\footnotetext{
* Corresponding author : E-mail : cereghin@cict.fr
}

basis of taxonomic composition (Sahuquillo et al. 2007, Céréghino et al. 2008). While great emphasis has been laid on species richness (Oertli et al. 2002, Williams et al. 2004) and species assemblage patterns in ponds (Briers \& Biggs 2005, Mergeay et al. 2006, Demeter \& Hartel 2007), little is known about patterns of biological traits of pond invertebrates (but see Cayrou \& Céréghino 2005). However, if broadly acceptable schemes are needed to support fundamental and applied research (Oertli et al. 2005), then comparisons of biological communities across biogeographic regions will be made easier using their biological attributes rather than using species lists (Usseglio-Polatera \& Tachet 1994).

Succession in ponds is marked by a sequence of plant communities which replace each other as a pond matures. As these plants die, they provide detritus and 
organic nutrients which enable more plants to become established. Thus, without human intervention, ponds progressively fill up with mud and aquatic vegetation, and eventually disappear. For instance, in the Causse du Quercy (France), hundreds of man-made ponds were progressively abandoned during the last decades. These ponds are therefore at various stages of natural filling. Their vegetation cover show a gradient from a low and sparse vegetation (e.g., bryophytes) colonizing thin layers of silt and/or mud, to extensive stands of submerged vegetation (e.g., Characea), and finally to a plant community dominated by emergent species such as Typha spp. (Angélibert et al. 2004). Assuming that vegetation cover is a good predictor of invertebrate communities in still waters (Gilinsky 1984, Jeppesen et al. 1997, Boix et al. 2004), we predicted that species with certain combinations of adaptations (e.g., traits related to survival, reproduction, or to food acquisition) will be selected by the nature and extent of vegetation in ponds (see also Southwood 1988, Townsend \& Hildrew 1994).

This paper completes a series of previous ones, where three model ponds $(1-3)$ were thoroughly investigated for the dynamics of their physical and chemical conditions (Angélibert et al. 2004), life history of macroinvertebrates (Cayrou \& Céréghino 2003, 2005) and dispersal/migration patterns of invertebrate and amphibian species (Angélibert \& Giani 2003, Marty et al. 2005). In the present study, we hypothesized that the biological traits of pond invertebrate communities differed significantly among ponds having different vegetal formations. We selected three small, permanent ponds in the karstic region of the 'Causses du Quercy' (SW France), showing sparse submerged to extensive emergent vegetation. Invertebrate biomasses were first recorded in the various mesohabitat types of each pond over a one-year period (biomass matrix), then species traits were described using a fuzzy-coding method (species traits matrix). A simultaneous analysis of the two matrices performed through a co-inertia analysis was used to investigate changes in species traits combinations (Chevenet et al. 1994) according to the type and extent of the pond vegetation.

\section{Material and methods}

\section{Study area}

The "Causses du Quercy" is a 2,156 $\mathrm{km}^{2}$ limestone plateau located in southwestern France. The area is identified as site fr7300909 of the Natura 2000 con- servation network. The plateau has no natural surface freshwater; however, it has over 300 artificial ponds (typically permanent, rectangular in shape and shallow, and sparsely distributed - ca 1 pond per $\mathrm{km}^{2}$ on average). These ponds, dug by man into the calcareous rock, were created to hold rainwater and support agricultural activities, and it is a technique that has been in practice since the $12^{\text {th }}$ century. Abandoned during the 1960s, the ponds are progressively filling with sediment and aquatic vegetation. Our study was conducted from November 2000 to November 2001 in three permanent ponds with a rocky substrate covered by fine sediment (hereafter called 1,2 and 3). Their main characteristics are shown in Table 1. A detailed list of invertebrate species and a thorough analysis of the physical and chemical features of the three study ponds can be found in Angélibert et al. (2004).

\section{Sampling}

In each pond, six samples were collected monthly from November 2000 to February 2001, then fortnightly from March to November 2001. This scheme allowed us to take into account the seasonal variations in assemblage patterns, because the growth of most species was markedly seasonal and many species were temporally segregated (see life history details in Cayrou 2004, Cayrou \& Céréghino 2003, 2005). We acknowledge that data from a larger set of ponds would have strengthened our research results. However, given the fast seasonal cycles and the temporal segregation of most species over the year, intensive field sampling and individual counts were required to obtain accurate characterizations of pond communities. Different techniques were used to obtain quantitative samples of aquatic invertebrates within each substrate type, each type of substrate requiring a specific sampling technique (Oertli 1993). At each pond, the percentage composition of substrate was visually described (mapped in Angélibert et al. 2004), and samples were distributed in proportion to the relative abundance of the substratum types (see Table 1). This scheme provided the best qualitative (all substrata were sampled) and quantitative (replicate sampleunits) estimates, with a rather low number of sample units per month (Céréghino et al. 2002). Thin layers of mud $(<5 \mathrm{~cm})$ deposited on the calcareous substrate and bryophytes were sampled using an air-lift sampler (Boulton 1985) (sampling area $186 \mathrm{~cm}^{2}$, mesh size of the net: $250 \mu \mathrm{m})$. Thick layers of mud $(>5 \mathrm{~cm})$ were sampled using a plastic core sampler (sampling area: $\left.28.2 \mathrm{~cm}^{2}\right)$. Small diameter cores $(40 \mathrm{~cm}$ high and $4.4 \mathrm{~cm}$ in diameter) were used to sample the submerged section 
Table 1. Main characteristics of the three study ponds (min-max values observed from monthly samples, November 2000 - November 2001), and distribution of sample units (substrate-specific samples, see text) in each pond (sampling method: $\mathrm{A}=$ air-lift sampler, $\mathrm{P}=\mathrm{plastic}$ box, $\mathrm{C}=\mathrm{core}$, see text). After Angélibert et al. (2004).

\begin{tabular}{|c|c|c|c|}
\hline & Pond 1 & Pond 2 & Pond 3 \\
\hline Elevation a.s.1. (m) & 357 & 350 & 350 \\
\hline Area $\left(\mathrm{m}^{2}\right)$ & 175 & 75 & 65 \\
\hline Maximum depth (m) & 1.60 & 0.50 & 0.60 \\
\hline Water temperature $\left(\min -\max ,{ }^{\circ} \mathrm{C}\right)$ & $0.50-27.20$ & $0.50-29$ & $0.50-31.20$ \\
\hline Suspended matter (min-max, mg/l) & $0.15-5.46$ & $0.59-10.35$ & $0.5-13.11$ \\
\hline $\mathrm{NO}_{2}(\min -\max , \mu \mathrm{g} / \mathrm{l})$ & $0-27.50$ & $0-108$ & $0-110.67$ \\
\hline $\mathrm{NO}_{3}(\min -\max , \mu \mathrm{g} / \mathrm{l})$ & $7.50-73$ & $12.20-216.67$ & $15-446.25$ \\
\hline Total Phosphorus (min-max, $\mu \mathrm{g} / \mathrm{l}$ ) & $3.12-30.21$ & $13.55-48.65$ & $31.10-125.77$ \\
\hline $\mathrm{SiO}_{2}(\min -\mathrm{max}, \mathrm{mg} / \mathrm{l})$ & $0.24-3.31$ & $0.25-1.90$ & $0.54-6.13$ \\
\hline \multicolumn{4}{|l|}{ Substrate composition (\%): } \\
\hline Mud & $70-90$ & $10-30$ & $5-10$ \\
\hline Bryophytes & $10-30$ & - & \\
\hline Chara spp. & - & $70-90$ & $10-20$ \\
\hline Typha latifolia & - & - & $60-90$ \\
\hline \multicolumn{4}{|l|}{ Number of sample units per month } \\
\hline Bryophytes & $\begin{array}{l}4 \text { (A) } \\
2(\mathrm{~A})\end{array}$ & $3(C)$ & $2(C)$ \\
\hline Chara spp. & - & $3(\mathrm{P})$ & $2(\mathrm{P})$ \\
\hline Typha latifolia & - & - & $2(\mathrm{C})$ \\
\hline
\end{tabular}

of Typha stems (Oertli \& Lachavanne 1995). The aerial part of the plant was cut at water level, and the remaining submerged part was quickly enclosed in the core and cut at approximately $35 \mathrm{~cm}$ under the surface of the water. The corresponding sampling area was estimated from the length and diameter of the collected part of Typha stem, which could be considered as cylindrical. Chara beds at mid-depth were sampled by rapidly enclosing plants in a plastic box $(7.5 \times 16 \times 11.5 \mathrm{~cm})$. The Chara plants were then cut with shears. The mean Chara mass obtained averaged $9.98 \mathrm{~g}$ dry weight per sample. The mean biomass of Chara in ponds 2 and 3 was estimated as $149 \mathrm{~g} / \mathrm{m}^{2}$ (dry weight) in the sampled areas, and this value was used to estimate invertebrate densities (and subsequently invertebrate biomass, see below), in Chara beds from the number of individuals and the dry weight of Chara caught with plastic box (Oertli 1993). Invertebrates were preserved in the field in $5 \%$ formalin.

After identification and counting in the laboratory, all invertebrates were dried at $60^{\circ} \mathrm{C}$ for 24 hours and then weighed to obtain biomass data. Biomass records per sample-units (b, mg Dry Weight per sample) were all converted to $\mathrm{mg} \mathrm{DW}$ per $1 \mathrm{~m}^{2}(\mathrm{~B})$, as $\mathrm{B}=(149 \mathrm{x}$ b) / 9.98. In all analyses, biomasses were used instead of density data. Biomass is more prone to reflect the functional role of species within assemblages, because larger individuals may have the greatest impact on the functional ecology of communities, even at low densities (Céréghino 2006). The detailed species list for each study pond can be found in Angélibert et al. (2004).

\section{Data analysis}

Correspondence analysis (CA) was used to ordinate the samples according to species' biomasses (Jongman et al. 1995), thus summarizing the variability of the data, and providing insights for the discussion of the subsequent species traits analysis. The significance of the axes was determined at $\mathrm{P}<0.05$ by testing the eigenvalues of the inertia matrix. Plots of the first two ordination axes usually capture most of the variance and consequently contain most of the information that is likely to be interpretable (Waite et al. 2000). Samples which were neighbours in the scatterplots were expected to define habitats with similar species assemblages. Conversely, samples having a large distance to each other were expected to be distant in the feature space, according to macroinvertebrate assemblages.

Categories for each biological trait were ordinal or nominal (Table 2). Species traits were: adult body size, number of generations per year, aquatic stage, reproduc- 
Table 2. Summary of the biological traits under consideration and their categories. In order to lighten the figures, codes for each trait category were used in Figure 1.

\begin{tabular}{|c|c|c|}
\hline Biological trait & Trait category & Code \\
\hline Adult body size & $\begin{array}{l}<2.5 \mathrm{~mm} \\
2.5-5 \mathrm{~mm} \\
5-10 \mathrm{~mm} \\
10-20 \mathrm{~mm} \\
20-40 \mathrm{~mm} \\
40-80 \mathrm{~mm}\end{array}$ & $\begin{array}{l}1 \\
2 \\
3 \\
4 \\
5 \\
6\end{array}$ \\
\hline \# generations per year & $\begin{array}{l}<1 \\
1 \\
>1\end{array}$ & $\begin{array}{l}1 \\
2 \\
3\end{array}$ \\
\hline Aquatic stage & $\begin{array}{l}\text { Egg } \\
\text { Larva } \\
\text { Pupa } \\
\text { Adult }\end{array}$ & $\begin{array}{l}1 \\
2 \\
3 \\
4 \\
\end{array}$ \\
\hline Reproduction mode & $\begin{array}{l}\text { Ovoviviparity + parental care } \\
\text { Isolated eggs } \\
\text { Isolated cemented eggs } \\
\text { Grouped eggs, cemented } \\
\text { Grouped eggs } \\
\text { Endophytic eggs } \\
\text { Terrestrial eggs } \\
\text { Asexual reproduction } \\
\text { Parthenogenesis }\end{array}$ & $\begin{array}{l}1 \\
2 \\
3 \\
4 \\
5 \\
6 \\
7 \\
8 \\
9\end{array}$ \\
\hline Dispersal mode & $\begin{array}{l}\text { Aquatic, passive } \\
\text { Aquatic, active } \\
\text { Aerial, passive } \\
\text { Aerial, active }\end{array}$ & $\begin{array}{l}1 \\
2 \\
3 \\
4 \\
\end{array}$ \\
\hline Resistance forms & $\begin{array}{l}\text { Eggs, statoblasts } \\
\text { Cocoon } \\
\text { Diapause } \\
\text { None }\end{array}$ & $\begin{array}{l}1 \\
2 \\
3 \\
4 \\
\end{array}$ \\
\hline Food & $\begin{array}{l}\text { Sediment }+ \text { bacteria } \\
\text { Fine detritus }<1 \mathrm{~mm} \\
\text { Coarse detritus }>1 \mathrm{~mm}\end{array}$ & $\begin{array}{l}1 \\
2 \\
3\end{array}$ \\
\hline & $\begin{array}{l}\text { Live microphytes } \\
\text { Live macrophytes } \\
\text { Dead animals }>1 \mathrm{~mm} \\
\text { Live microinvertebrates } \\
\text { Live macroinvertebrates } \\
\text { Vertebrates }\end{array}$ & $\begin{array}{l}4 \\
5 \\
6 \\
7 \\
8 \\
9\end{array}$ \\
\hline Feeding group & $\begin{array}{l}\text { Absorber (through tegument) } \\
\text { Sediment feeder } \\
\text { Shredder } \\
\text { Grazer - scraper } \\
\text { Piercer (algae or animal prey) } \\
\text { Predator } \\
\text { Parasite }\end{array}$ & $\begin{array}{l}1 \\
2 \\
3 \\
4 \\
5 \\
6 \\
7\end{array}$ \\
\hline Respiration mode & $\begin{array}{l}\text { Tegument } \\
\text { Gill } \\
\text { Plastron } \\
\text { Spiracle } \\
\text { Hydrostatic vesicles }\end{array}$ & $\begin{array}{l}1 \\
2 \\
3 \\
4 \\
5\end{array}$ \\
\hline Temperature tolerance & $\begin{array}{l}\text { Stenothermic }\left(<15^{\circ} \mathrm{C}\right) \\
\text { Stenothermic }\left(>15^{\circ} \mathrm{C}\right) \\
\text { Eurythermic }\end{array}$ & $\begin{array}{l}1 \\
2 \\
3\end{array}$ \\
\hline $\mathrm{pH}$ tolerance & $\begin{array}{l}<4 \\
4-4.5 \\
4.5-5 \\
5-5.5 \\
5.5-6 \\
>6\end{array}$ & $\begin{array}{l}1 \\
2 \\
3 \\
4 \\
5 \\
6\end{array}$ \\
\hline Trophic level of habitat & $\begin{array}{l}\text { Oligotrophic } \\
\text { Mesotrophic } \\
\text { Eutrophic }\end{array}$ & $\begin{array}{l}1 \\
2 \\
3\end{array}$ \\
\hline Mesohabitat preferences & $\begin{array}{l}\text { Cobbles - Pebbles } \\
\text { Gravels } \\
\text { Sand }\end{array}$ & $\begin{array}{l}1 \\
2 \\
3 \\
\end{array}$ \\
\hline Mesohabitat preferences & $\begin{array}{l}\text { Silt } \\
\text { Macrophytes }\end{array}$ & $\begin{array}{l}4 \\
5 \\
\end{array}$ \\
\hline
\end{tabular}

\begin{tabular}{|c|c|c|}
\hline Biological trait & Trait category & Code \\
\hline \multirow[t]{4}{*}{ Mesohabitat preferences } & Microphytes & 6 \\
\hline & Roots, twigs & 7 \\
\hline & Dead leaves & 8 \\
\hline & Mud & 9 \\
\hline \multirow[t]{6}{*}{ Habitat types } & River & 1 \\
\hline & Banks & 2 \\
\hline & Ponds (permanent) & 3 \\
\hline & Peat bogs, marshes & 4 \\
\hline & Temporary water bodies & 5 \\
\hline & $\begin{array}{l}\text { Lakes } \\
\text { Groundwaters }\end{array}$ & 6 \\
\hline \multirow[t]{8}{*}{ Locomotion } & Flight & 1 \\
\hline & Surface swimmer & 2 \\
\hline & Swimmer & 3 \\
\hline & Crawler & 4 \\
\hline & Burrower & 5 \\
\hline & Interstitial & 6 \\
\hline & Temporary attached & 7 \\
\hline & Permanently attached & 8 \\
\hline \multirow[t]{4}{*}{ Colonization period } & Autumn & 1 \\
\hline & Winter & 2 \\
\hline & Spring & 3 \\
\hline & Summer & 4 \\
\hline \multirow{3}{*}{ Dispersal ability } & High & 1 \\
\hline & Medium & 2 \\
\hline & Low & 3 \\
\hline \multirow{5}{*}{$\begin{array}{l}\text { Cohort production } \\
\text { interval } \\
(\mathrm{CPI})\end{array}$} & $<1$ month & 1 \\
\hline & $1-3$ months & 2 \\
\hline & $4-6$ months & 3 \\
\hline & $6-12$ months & 4 \\
\hline & $>1$ year & 5 \\
\hline \multirow{3}{*}{ Adult longevity } & $<15$ days & 1 \\
\hline & 1 month & 2 \\
\hline & $1-6$ months & 3 \\
\hline \multirow{2}{*}{ Adult longevity } & $6-12$ months & 4 \\
\hline & $>1$ year & 5 \\
\hline \multirow{4}{*}{ Water depth preference } & Surface & 1 \\
\hline & Middle & 2 \\
\hline & Bottom & 3 \\
\hline & No preference & 4 \\
\hline \multirow[t]{7}{*}{ Mating period } & Winter & 1 \\
\hline & Early spring & 2 \\
\hline & Spring & 3 \\
\hline & Early summer & 4 \\
\hline & Summer & 5 \\
\hline & Early autumn & 6 \\
\hline & Autumn & 7 \\
\hline \multirow[t]{5}{*}{ \# eggs per female } & $0-50$ & 1 \\
\hline & $50-100$ & 2 \\
\hline & $100-200$ & 3 \\
\hline & $200-500$ & 4 \\
\hline & $>500$ & 5 \\
\hline \multirow{7}{*}{ Emergence period } & Winter & 1 \\
\hline & Early spring & 2 \\
\hline & Spring & 3 \\
\hline & Early summer & 4 \\
\hline & Summer & 5 \\
\hline & Early autumn & 6 \\
\hline & Autumn & 7 \\
\hline \multirow[t]{7}{*}{ Hatching period } & Winter & 1 \\
\hline & Early spring & 2 \\
\hline & Spring & 3 \\
\hline & Early summer & 4 \\
\hline & Summer & 5 \\
\hline & Early autumn & 6 \\
\hline & Autumn & 7 \\
\hline Consumer level & Primary consumer & 1 \\
\hline & Primary-secondary consumer & 2 \\
\hline & Predator & 3 \\
\hline & Top-predator & 4 \\
\hline
\end{tabular}


tion mode, dispersal mode (active vs. passive), resistance forms, food, feeding group, respiration mode, temperature tolerance, $\mathrm{pH}$ tolerance, trophic level of habitat (oligotrophic to eutrophic), habitat types (ponds, lakes, rivers, streams, etc.), mesohabitat preferences, locomotion, colonization period, dispersal capability, cohort production interval, adult longevity, water depth, mating period, fecundity (number of eggs per female), emergence period, hatching period, trophic level (primary to secondary consumer) (Table 2). Life history traits (e.g., hatching and emergence periods, number of generations per year, etc.) were obtained from thorough studies of species' life histories in ponds 1 - 3 (Cayrou 2004, Cayrou \& Céréghino 2003, 2005). Ecological (e.g., functional feeding group, aquatic stage) and physiological (e.g., respiration) traits were obtained from Tachet et al. (2000). Species traits information was then structured using a fuzzy-coding technique (Chevenet et al. 1994): scores ranged from ' 0 ', indicating 'no affinity' to ' 5 ', indicating 'high affinity' for a given species traits category. Note that some taxa were not concerned by all biological traits (e.g., crustaceans are not concerned by "emergence period"). In this case, a '0' score was given to the corresponding trait categories. Here, the discriminative weight of the taxa for this particular variable is zero (see also Chevenet et al. 1994, Usseglio-Polatera et al. 2000). This matrix was studied by a 'Fuzzy Correspondence Analysis' (FCA) (Chevenet et al. 1994). Finally, a simultaneous analysis of the two matrices (species distributions and species traits matrices) was performed using co-inertia analysis (CoA, Dolédec \& Chessel 1994). This analysis studies co-structure by maximizing covariance between faunal and biological traits ordination scores in the first two analyses (Dray et al. 2003). Trends in biological traits were quantified by correlation ratios (Chevenet et al. 1994). Correlation ratios, ranging from 0 to 1 , allowed the identification of species traits that were best explained by the factorial axes. These ratios represent proportions of the total variance explained by each axis to depict the separation among modalities of a variable. All analyses were performed with ADE software (Thioulouse et al. 1997).

\section{Results}

The co-inertia analysis (Fig. 1) of taxa distributions and their biological traits made it possible to derive some patterns in trait combinations among ponds. The scatterplot of samples using the first two axes of the CoA primarily suggested a distribution gradient ranging from pond 1 (bottom area of the graph) to pond 3 (top area), while samples in the right area were rather taken on muddy substrata, and samples in the left area of the scatterplot were rather taken on vegetation (Figure 1a). Only those biological traits which were significantly correlated to axes 1 and/or $2(\mathrm{p}<0.05)$ were kept in the figure (Fig. 1b). Pond 1 was characterized by multivoltine species (with 2 or 3 generations per year), low cohort production intervals ( $<6$ months), small body size $(<20 \mathrm{~mm})$ and short-lived adults $(<$ 15 days). The food ingested by macroinvertebrates was primarily microorganisms, fine detritus $(<1 \mathrm{~mm})$, and live micro- and macrophytes. Food was mainly collected by sediment-feeding, grazing and shredding, and the species assemblage was dominated by primary consumers.

On the opposite trend, pond 3 was characterized by univoltine species (with 1 generation per year), high cohort production intervals (12 months or more), large body size $(20-40 \mathrm{~mm})$ and long-lived adults $(6-12$ month). The dominant food type was macrophytes, live and dead animals (including micro- and macroinvertebrates, and vertebrates such as toads). Food was collected by grazing, shredding, and by predation, and the community mixed primary and secondary consumers. However, the later functional groups were spatially segregated within the pond (primary consumers in vegetation samples, secondary consumers in mud samples).

Finally, pond 2 showed intermediate trends, mixing the above mentioned modalities of biological traits within its macroinvertebrate community. The invertebrates showed some traits typically associated to pond 1 (e.g., low CPI, small adults), but also more specific traits such as high dispersal capability and functional diversity (carnivorous, detritivorous and herbivorous taxa). It should be noted that dispersal capability was the highest in pond 2 invertebrates which were mostly active dispersers (mostly insects with winged adults), while pond 1 and pond 3 invertebrates were rather passive dispersers (phoresy), and showed a lower dispersal capability.

\section{Discussion}

Ponds are ideal model systems to study general community ecology (e.g., importance of regional and/ or local factors in determining community structure; relationship between diversity and ecosystem function, etc., De Meester et al. 2005, Carchini et al. 2007). Several factors play a role in shaping pond communities, such as dispersal/colonization patterns, connectivity of the pond network, selective attractiveness of certain ponds within the landscape, and biotic interactions and 

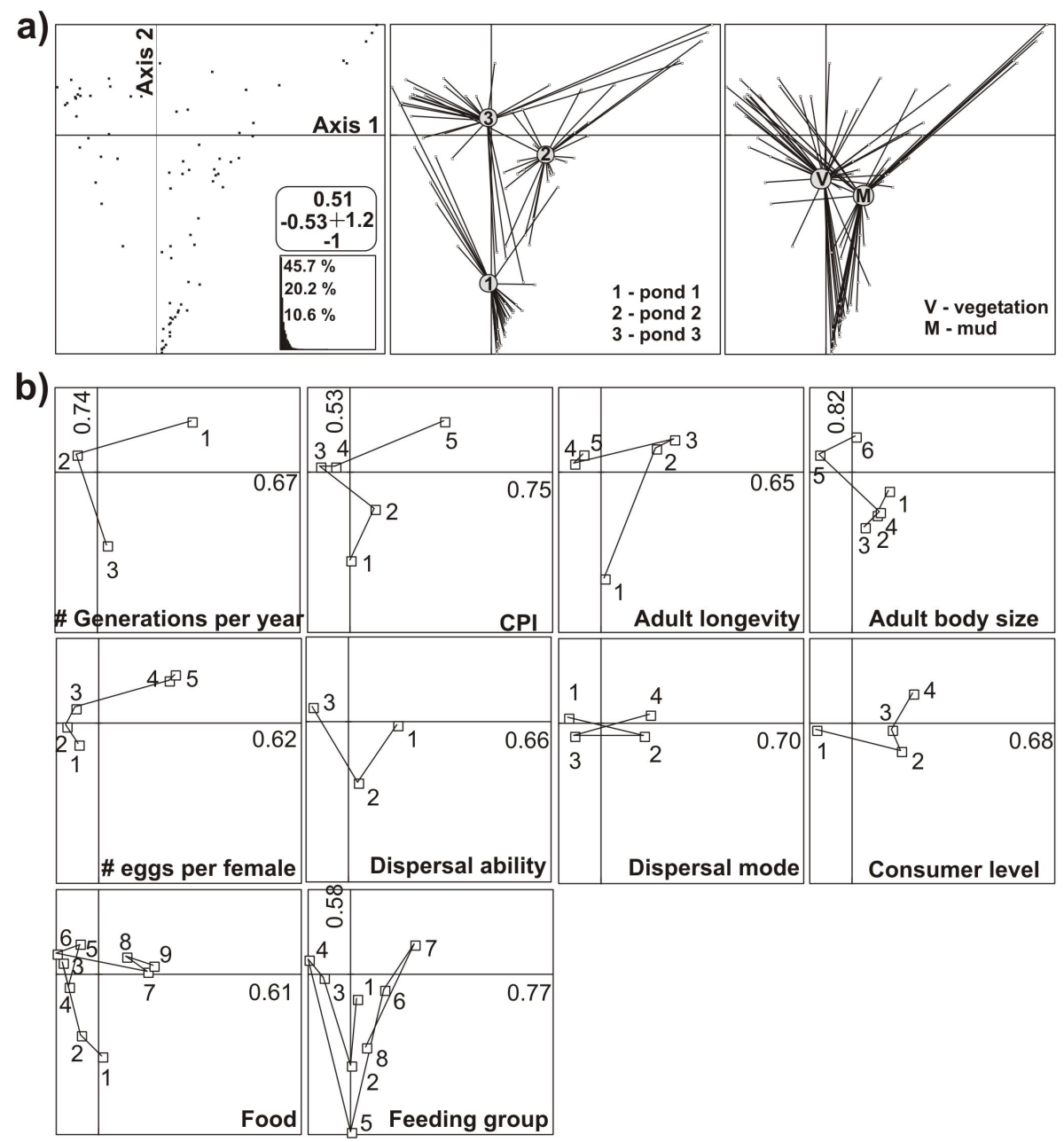

Fig. 1. Co-Inertia analysis results: a) Left panel: ordination of the 234 samples on the first two axes of the CoA (Axes 1 and 2 contributed to 45.7 and $20.2 \%$ of the overall variance, respectively); middle panel: grouping of samples according to ponds $1-3$; right panel: grouping of samples according to substrate type (vegetation vs mud). b) Distribution of species traits categories on the first two axes (only significant traits are illustrated). Correlation ratios for each species trait are indicated on the axes (see Table 2 for coding of categories). Categories are positioned at the weighted average of their species.

the presence of suitable physical habitats. We focused on three very different (but intensively sampled) ponds, rather than on snapshot samples of larger numbers of water bodies. Many species had fast seasonal life cycles, and were temporally segregated within each pond (detailed in Cayrou \& Céréghino 2005). We did not mention temporal trend in biological traits because species seasonality affected community composition, but not biological attributes. Indeed, life history pat- terns enable many species with similar requirements to utilize these small ecosystems (Cayrou \& Céréghino 2005.), temporal segregation certainly reducing interspecific competition for food and habitat resources. Nevertheless, we obviously recorded biologically and ecologically distinct communities when comparing the three ponds. The biological traits of invertebrates in pond 1 suggested that species allocated much energy to reproduction: larval development was fast so that sex- 
ual maturity was quickly reached, eggs were laid over a short period, and the life span of adults (which had a short emergence period, and a low dispersal capability) was brief. Those populations are believed to be selected by unstable habitats or by habitats fluctuating in an unpredictable way (MacArthur \& Wilson 1967, Pianka 1970, Begon et al. 1996), a description of conditions which fits well with pond 1 , where structured mesohabitats are scarce or absent (open-water, thin layers of mud and few bryophytes only). The traits of invertebrates in pond 3 therefore suggested that fewer energy was allocated to reproduction and dispersal, whereas habitat occupancy and resource use was favoured by larger body size, long-lived organisms, and a higher diversity of feeding groups. Those populations are believed to be selected by more stable and structured habitats allowing interspecific competition and/or resource partitioning through the spatial segregations of species (Begon et al. 1996). Because species respond differently to different types of environmental heterogeneity, differences in species trait combinations among ponds are unlikely to be a random pattern (Covich et al. 2004). The structure (and age) of the vegetal formation apparently plays a role in the related changes, almost certainly through the structuring role of macrophytes on the habitat, that may allow the succession of species with different requirements during pond ontogeny. Subsequently, we suggest that micro- to meso-habitat changes within the ponds over time might force the termination of former functional interactions by influencing their associated fauna. Consequently, this succession might override the attractiveness that the ponds could have for some species in the area. However, further studies would be necessary to test the idea of an "ontogenetic succession of pond invertebrates", and to disentangle the processes permitting later dominant species to overcome the earlier ones.

\section{Acknowledgements}

Financial support for this study was provided by EU funds (FEDER), FNSE, and Région Midi-Pyrénées. We wish to thank J. Cayrou for performing the statistical analyses, and two anonymous reviewers for their constructive criticism on an earlier version of this paper.

\section{References}

Angélibert S. \& Giani N. 2003. - Dispersal characteristics of three odonate species in a patchy habitat. Ecography, 26, 13-20.

Angélibert S., Marty P., Céréghino R. \& Giani N. 2004. - Seasonal variations in physico-chemical characteristics of ponds: implica- tions for biodiversity conservation. Aquat. Conserv. Mar. Fresh. Ecosyst., 14, 439-456.

Begon M., Harper J.L. \& Townsend C.R. 1996. Ecology: individuals, populations and communities (third edition). Blackwell Science, Oxford, UK.

Boix D., Sala J., Quintana X.D. \& Moreno-Amich R. 2004. - Succession of the animal community in a Mediterranean temporary pond. J. N. Amer. Benthol. Soc., 23, 29-49.

Boulton A.J. 1985. - A sampling device that quantitatively collects benthos in flowing or standing waters. Hydrobiologia, 127, 31-39.

Briers R.A. \& Biggs J. 2005. - Spatial patterns in pond invertebrate communities: separating environmental and distance effects. Aquat. Conserv. Mar. Fresh. Ecosyst., 15, 549-557.

Carchini G., Della Bella V., Solimini A.G. \& Bazzanti M. 2007. Relationships between the presence of Odonate species and environmental characteristics in lowland ponds of Central Italy. Ann. Limnol. - Int. J. Lim., 43, 81-87.

Cayrou J. 2004. - Dynamique des populations et structure des communautés d'invertébrés de mares rocheuses du Parc Naturel Régional des Causses du Quercy (Lot, France). PhD Thesis, University Toulouse III.

Cayrou J. \& Céréghino R. 2003. - Life history, growth and secondary production of Caenis luctuosa and Cloeon simile (Ephemeroptera) in a small pond, SW France. Aquat. Insect., 25, 191-201.

Cayrou J. \& Céréghino R. 2005. - Life cycle phenology of some aquatic insects: implications for pond conservation. Aquat. Conserv. Mar. Fresh. Ecosyst., 15, 559-571.

Céréghino R. 2006. - Ontogenetic diet shifts and their incidence on ecological processes: a case study using two morphologically similar stoneflies (Plecoptera). Acta Oecol., 30, 33-38.

Céréghino R., Cugny P. \& Lavandier, P., 2002. - Influence of intermittent hydropeaking on the longitudinal zonation patterns of benthic invertebrates in a mountain stream. Int. Rev. Hydrobiol., 87, 47-60.

Céréghino R., Biggs J., Oertli B. \& Declerck S. 2008. - The ecology of European ponds: defining the characteristics of a neglected freshwater habitat. Hydrobiologia, 597, 1-6.

Chevenet F., Dolédec S. \& Chessel D. 1994. - A fuzzy coding approach for the analysis of long-term ecological data. Freshwat. Biol., 31, 295-309.

Covich A.P., Austen M.C., Bärlocher F., Chauvet E., Cardinale B.J., Biles C.L., Inchausti P., Dangles O., Solan M., Gessner M.O., Statzner B. \& Moss B. 2004. - The Role of Biodiversity in the Functioning of Freshwater and Marine Benthic Ecosystems. Bioscience, 54, 767-775.

De Meester L., Declerck S., Stoks R., Louette G., Van de Meutter F., De Bie T., Michels E. \& Brendonck L. 2005. - Ponds and pools as model systems in conservation biology, ecology and evolutionary biology. Aquat. Conserv. Mar. Fresh. Ecosyst., 15, 715-726.

Demeter L. \& Hartel T. 2007. - A rapid survey of large branchiopods in Romania. Ann. Limnol. - Int. J. Lim., 43, 101-105.

Dimitriou E., Karaouzas I., Skoulikidis N. \& Zacharias I. 2006. Assessing the environmental status of Mediterranean temporary ponds in Greece. Ann. Limnol. - Int. J. Lim., 42, 33-41.

Dolédec S. \& Chessel D. 1994. - Co-inertia analysis: an alternative method for studying species-environment relationships. Freshwat. Biol., 31, 277-294.

Dray S., Chessel D. \& Thioulouse J. 2003. - Co-Inertia analysis and the linking of ecological data tables. Ecology, 84, 3078-3089.

E.P.C.N. 2007. - Developing the pond manifesto. Ann. Limnol. - Int. J. Lim., 43, 221-232.

Gilinsky E. 1984. - The role of fish predation and spatial heterogeneity in determining benthic community structure. Ecology, 65, 
$455-468$.

Jeppesen E., Søndergaard Ma., Søndergaard Mo. \& Christoffersen K. 1997. - The structuring role of submerged water plants in lakes. Ecological Studies Series, 131. Springer, New York, USA.

Jongman R.H.G., Ter Braak, C.J.F. \& van Tongerenm O.F.R. 1995. - Data analysis in community and landscape ecology. Cambridge: Cambridge University Press, UK.

Karaus U., Adler L. \& Tockner K. 2005. - Concave islands: habitat heterogeneity of parafluvial ponds in a grave-bed river. Wetlands, 25, 26-37.

Marty P., Angélibert S., Giani N. \& Joly P. 2005. - Directionality of pre- and post-breeding migrations of a marbled newt population (Triturus marmoratus): implications for buffer zone management. Aquat. Conserv. Mar. Fresh. Ecosyst., 15, 215-225.

MacArthur R.H. \& Wilson E.O. 1967. - The theory of island biogeography. Princeton University Press, Princeton, New Jersey.

Mergeay J., Declerck S., Verschuren D. \& De Meester, L. 2006. Daphnia community analysis in shallow Kenyan lakes and ponds using dormant eggs in surface sediments. Freshwat. Biol., 51, 399411.

Nicolet P., Ruggiero A. \& Biggs J. 2007. - Second European Pond Workshop: Conservation of pond biodiversity in a changing European landscape. Ann. Limnol. - Int. J. Lim., 43, 77-80.

Oertli B. 1993. - Leaf litter processing and energy flow through macroinvertebrates in a woodland pond (Switzerland). Oecologia, 96, 466-477.

Oertli B. \& Lachavanne J.B. 1995. - The effects of shoot age on colonization of an emergent macrophyte (Typha latifolia) by macroinvertebrates. Freshwat. Biol., 34, 421-431.

Oertli B., Auderset-Joye D., Castella E., Juge R., Cambin D. \& Lachavanne J.B. 2002. - Does size matter? The relationship between pond area and biodiversity. Biol. Conserv., 104, 59-70.

Oertli B., Biggs J., Céréghino R., Grillas P., Joly \& P. Lachavanne J.B. 2005. - Conservation and monitoring of pond biodiversity: introduction. Aquat. Conserv. Mar. Fresh. Ecosyst., 15, 535-540.
Pianka E.R. 1970. - On r- and K-selection. Am. Nat., 104, 592-597.

Pyke C.R. 2005. - Assessing suitability for conservation action: Prioritizing interpond linkages for the California tiger salamander. Conserv. Biol., 19, 492-503.

Sahuquillo M., Poquet J.M., Rueda J. \& Miracle M.R. 2007. - Macroinvertebrate communities in sediment and plants in coastal Mediterranean water bodies (Central Iberian Peninsula). Ann. Limnol. - Int. J. Lim., 43, 117-130.

Scheffer M., van Geest. G.J., Zimmer K., Jeppesen E., Sondergaard M., Butler M.G., Hanson M.A., Declerck S. \& De Meester L. 2006. - Small habitat size and isolation can promote species richness: second-order effects on biodiversity in shallow lakes and ponds. Oikos, 112, 227-231.

Southwood T.R.E. 1988. - Tactics, strategies and templets. Oikos, 52, 3-18.

Tachet H., Richoux P., Bournaud M. \& Usseglio-Polatera P. 2000. Invertébrés d'eau douce. Systématique, biologie, écologie. CNRS Editions, Paris.

Thioulouse J., Chessel D., Dolédec S. \& Olivier J.M. 1997. - ADE-4: a multivariate analysis and graphical display software. Stat. Comput., 7, 75-83.

Townsend C.R. \& Hildrew A.G. 1994. - Species traits in relation to a habitat templet for river systems. Freshwat. Biol., 31, 265-275.

Usseglio-Polatera P. \& Tachet H. 1994. - Theoretical habitat templet, species traits, and species richness: Plecoptera and Ephemeroptera in the Upper Rhône River and its floodplain. Freshwat. Biol., 31, 357-375.

Waite I.R., Herlihy A.T., Larsen D.P. \& Klemm D.J. 2000. - Comparing strength of geographic and nongeographic classifications of stream benthic macroinvertebrates in the Mid-Atlantic Highlands, USA. J. N. Amer. Benthol. Soc., 19, 429-441.

Williams P., Whitfield M., Biggs J., Bray S., Fox G., Nicolet P. \& Sear D. 2004. - Comparative biodiversity of rivers, streams, ditches and ponds in an agricultural landscape in Southern England. Biol. Conserv., 115, 329-341 